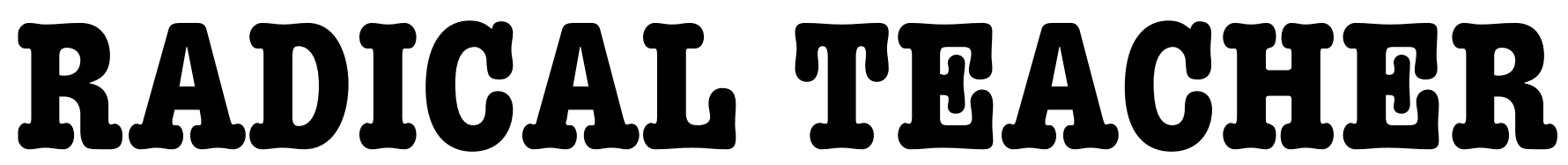

A SOCIALIST, FEMINIST, AND ANTI-RACIST JOURNAL ON THE THEORY AND PRACTICE OF TEACHING

\title{
Kiss of the Spider Woman
}

(RADICAL TEACHER NO.29, 1985)

by Louis Kampf

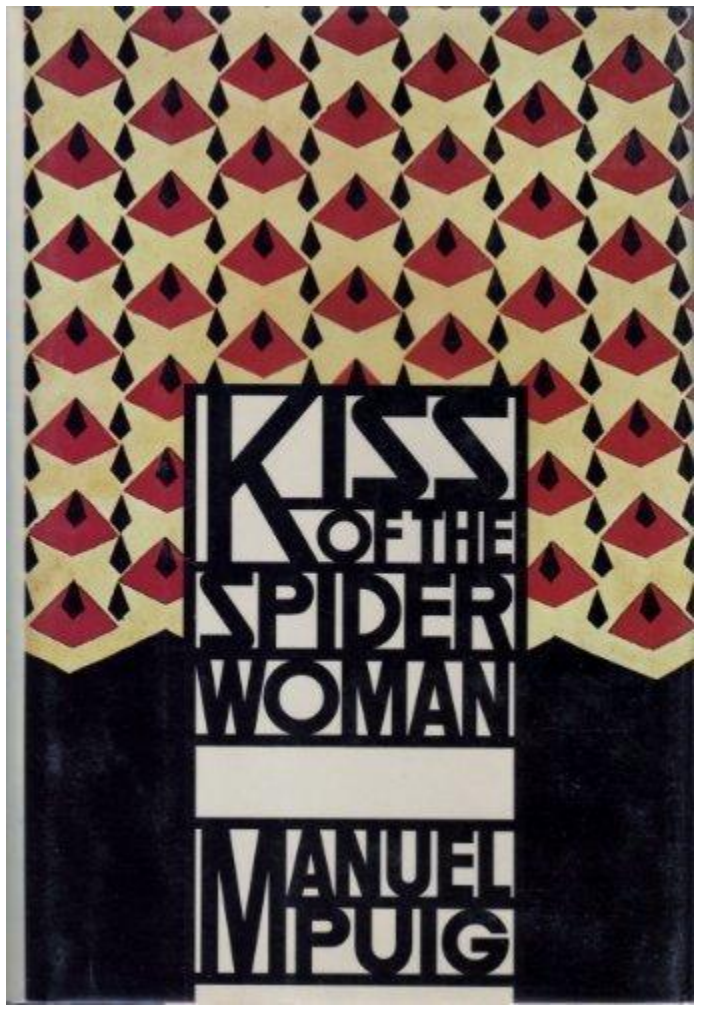

KISS OF THE SPIDER WOMAN BY MANUEL PUIG (1976) 
Kiss of the Spider Woman. Manuel Puig. Translated from Spanish by Thomas Colchie. Vintage.

T

his novel, written by an Argentinian exile now living in New York City, follows the evolving relationship of two male prisoners locked up in the same cell. One is in jail for being a revolutionary Marxist, the other for being gay. Circumstances force them to relate to each other's ways of feeling, thinking, loving. The gay prisoner delights in telling the plots of campy old movies. The Marxist has ideological difficulties with these movies; the resulting clash of sensibilities is the device through which Puig unfolds both the plot and the politics of the novel. Not since the publication of Doris Lessing's The Golden Notebook have I read a work of fiction which so resolutely and convincingly ties the political to the sexual. The prisoners' discussions, though deadly serious, are very funny. Though ultimately tragic, the suspenseful plot makes one feel good about some human beings.

I used Kiss in "Sex Roles in European and Latin American Fiction," a women's studies course I team-taught at M.I.T. with a woman. The students ( 23 women, 5 men) reacted very favorably to the novel, though two of the women were offended by the descriptions of gay male sex. Discussion was lively, largely sane, though often misguided. The teacher should be prepared to deal with some students' weird, though not necessarily malicious, notions. The warm human generosity and powerful intelligence of Kiss ultimately convinced the students that it was intimately related to their own lives.

The novel can readily be used for courses on modern fiction, gay studies, film, politics, and much else. 